DOE/MC/26026-95/C0404

$$
\cos f-9410262--1
$$

\title{
MULTISTRATA EXPLORATION AND PRODUCTION STUDY
}

\section{Authors:}

Linda Hawkins

Ronald G. Brunk

Felah Al-Saadoon

James Weekley

\section{Contractor:}

The College of West Virginia

P.O. Box AG

Beckley, WV 25802-2830

\section{Contract Number:}

DE-AC21-89MC26026

\section{Conference Title:}

Coalbed Methane Utilization

\section{Conference Location:}

Katowice, Upper Silesia, Poland

\section{Conference Dates:}

October 5-7, 1994

\section{Conference Sponsor:}

U.S. EPA, Commission of the European Communities, U.S. DOE METC, and Resource Enterprises, Inc. 


\section{DISCLAIMER}

This report was prepared as an account of work sponsored by an agency of the United States Government. Neither the United States Government nor any agency thereof, nor any of their employees, makes any warranty, express or implied, or assumes any legal liability or responsibility for the accuracy, completeness, or usefulness of any iuformation, apparatus, product, or process disclosed, or represents that its use would not infringe privately owned rights. Reference herein to any specific commercial product, process, or service by trade name, trademark, manufacturer, or otherwise does not necessarily constitute or imply its endorsement, recommendation, or favoring by the United States Government or any agency thereof. The views and opinions of authors expressed herein do not necessarily state or reflect those of the United States Government or any agency thereof.

This report has been reproduced directly from the best available copy.

Available to DOE and DOE contractors from the Office of Scientific and Tecbuical Information, 175 Oak Ridge Turnpike, Oak Ridge, TN 37831; prices available at (615) $576-8401$.

Available to the public from the National Technical Information Service, U.S. Department of Commerce, 5285 Port Royal Road, Springfield, VA 22161; phone orders accepted at (703) 487-4650. 


\section{DISCLAIMER}

Portions of this document may be illegible in electronic image products. Images are produced from the best available original document. 


\section{Multistrata Exploration and Production study}

CONTRACT INFORMATION

Contract Number

Contractor

Contract Project Manager

Principal Investigators

METC Project Manager

Period of Performance

schedule of Milestones
DE-AC21-89MC26026

The College of West Virginia P.O. Box AG Beckley, WV USA 25802-2830

Linda K. Hawkins

Ronald G. Brunk

Felah T. Al-Saadoon

James L. Weekley

Charles W. Byrer

October 1, 1989 to November 30, 1994

FY 94 Program Schedule

Develop New Field Plan
Conduct workover on TW1
Conduct workover on TW3

Final Report

\section{OBJECTIVES}

The objective of this project was to develop and verify a geotechnical/geostatistical approach to find natural gas resources and to verify the process by drilling, completing, testing, and producing wells located by the process.

\section{BACRGROUND INFORMATION}

Research conducted on the Eccles $7.5^{\prime}$ quadrangle in Raleigh county, WV, in 1990, pinpointed several target areas. Immediate landowners, gas companies, and mineral rights owners were contacted to determine their willingness to assist the college in conducting the research. Extensive talks were held and as a result, agreements were drawn up between the college and the owners and Test Well 1 was completed in May 1991 and Test Wells 2 and 3 in November, 1991. The wells were shut in for one year thereafter while the parties involved negotiated agreements. The wells were placed on line at the close of fiscal year 1992. The following section summarizes the activities conducted in fiscal year 1993. 


\section{PROJECT DESCRIPTION}

Activities for the Multistrata Project began in Fiscal Year 1993 with the placement of the three Test Wells into production full force. By turning all three wells in line october 1, 1992, gas began flowing as designed by the agreements negotiated in Fiscal Year 1992. All the parties involved began to see tangible results as the gas moved from the College's gathering lines into the systems of Ramco, Columbia, and Mountaineer Gas Companies.

The College of West Virginia began work as specified in the Field Test Plan for Phase II, Task 12. A new consulting agreement, based on the Task 12 outline, was drafted and forwarded to potential new subcontractors. American Pump Company, headquartered in Monroe, LA, was selected as the college's subcontractor.

One of the first activities undertaken was to study possible results of installing a compressor in the College's system. This included assessment of such issues as: impact on the parties involved, effects on the wells' production and the system's overall performance, and sizing and pricing the compressor. This task has been addressed on an ongoing basis over the past ten months. No final decisions have been made due to constraints placed on us by gas companies involved and cost considerations.

The Test Well 1 and Test Well 3 sites were successfully automated. The college coordinated the automation activities which included selecting and installing electric motors and controls for each site. It also required electricians and Appalachian Power Company to set several poles, hang 5000 feet of line, and install two transformers.

Prior to running electricity to these sites, the pumps used to dewater the coal seams were operated on a manual basis. By running them 12 hours a day, three days per week, coal gas production increased an average 6 mofd. Following automation, production from the coals increased another 4 mofd on average. A number of pump rates and schedules were attempted in order to achieve maximum dewatering. None of the results, however, met our expectations.

Well data and histories were extensively analyzed to determine accurate tubing tallies and depth placement of the pumps on TWI and TW3. Evidence seemed to indicate that the pump on TW3 should be lowered approximately 60 feet. It also appeared that gas locking was a persistent problem on TW1. A decision was made, as a result of these problems, to develop a workover plan and to schedule workover rigs to move on site.

Rigs were contracted and moved on site July 19, 1993, and workover continued through July 30. Rigs were also on site for 13 days in August.

On TW1, the 2 and $3 / 8^{\prime \prime}$ and 1 and $1 / 2 "$ strings were pulled, tallied, inspected, and repaired. The pump jack was replaced with a progressive cavity pump and a drip tube was added for better water/gas separation. All zones were swabbed independently with poor water recovery on each run. Each zone was producing less than three barrels of water per day. 
TW1 was also flow tested extensively at atmosphere with good results. The coals averaged 30 mcfd, the Ravencliff sandstone 60 mcfd, and the Big lime 40 mofd.

A small acid job utilizing 800 gallons of $15 \%$ HCL was attempted on the Big Lime formation. We felt that the acid might clean out the perforations and the fractures from the original frac job. The zone went on vacuum for a few days and then slowly began to recover. Production tailed off but returned to previous levels after four weeks.

Workover on Test Well 3 included pulling, tallying, and repairing the tubing strings, pump assembly, rods, and all parts downhole. A drip tube was also placed on this well below the pump for better water/gas separation. The improper depth placement of the pump on this well was verified. Two joints of 1 and $1 / 2$ " were inadvertently left out of the hole during some work about a year earlier. As a result, the pump was landed just above the perfs at the Poca coal seam. This was the cause, as suspected, of the continuous gas interference while pumping the coals. The pump has now been placed 60 feet below the Poca coal and should enable us to adequately dewater the seam.

Attention was focused next on the Ravencliff Sandstone. This formation was found to be uneconomical with a maximum gas production of $2 \mathrm{mcf}$ and $15 \mathrm{bbls}$ of water per day. All necessary paperwork for plugging this zone was completed, but another approach was first attempted. Both strings were pulled out of the hole, and the 4 and $1 / 2$ " casing was cut at 1413 feet and removed. This opened the well up completely and allowed the water from the coal seam to simply fall downhole. Calculations indicated that the Ravencliff formation would accept the coal water, thereby solving our water disposal problems. The Ravencliff, however, has not taken the water up to this point.

The coals continue to show good potential, and averaged 35 mcfd when flowed to atmosphere. Dewatering of the Poca coal, however, has been hindered by malfunctioning pump off switches and $a$ high number of shut-in periods imposed upon us by Columbia Gas and Ramco Gas. The wells were shut in 6 days in June, 12 days in July, 4 days in August, and 13 in September. These shut-ins affected not only our wells, but all the wells in the area.

Water disposal has also been addressed on a continuing basis over the past few months. currently, we have permission from the state of West Virginia to apply water from the coal seams directly to the surface since the coal seam water has been analyzed and found to be potable. There are certain guidelines, of course, such as requirements to monitor the disposal, to avoid erosion, etc. Several meetings have been held with the state oil \& Gas Division and the Division of Environmental Protection, and the subject will continue to be discussed. We hope to eventually obtain permission from them to implement our water disposal plan. our plan will include a drainage field with perforated pipe for the coal water, and a line and tank at the foot of the hill for the brine from the deep zones.

It should also be noted that 
water production from the coals is minimal. Water from the coals on TW1 averages about 2.2 bbls per pumping hour, and TW3 coal water is only 1.2 bbls per actual pumping hour. Based on swabbing and echometer tests done during workover, the water influx rate appears to be near 2 bbls per day from the coals on each well.

The gas production overall from the three Project Test Wells has been exceptional. TW1 has proven to be extremely successful with an average production of 52 mcfd for 1993 (prior to workover activities). This well far surpasses most wells in the region since many wells in southern West virginia typically produce $8-12$ mcfd. This makes TW2 (10 mcfd), comparatively speaking, an average well for the area. TW3 may be the most interesting of the three since its production ( $15 \mathrm{mcfd}$ ) is drawn almost entirely from the Poca coal Seam. Circumstances have thus far prevented us from adequately dewatering and producing this well; but, even so, it still outproduces the average conventional well in the area.

work is currently underway which will allow for enhanced production from the college wells. This involves installation of a two-phase, $20 \mathrm{hp}$ gas operated compressor into the main sales line. The college of West Virginia gathering system will be tied directly into a system owned by another local producer and will necessitate the laying of 700 feet of additional pipeline. The compressor will be equipped to suction 1 psi and discharge at 75 psi for delivery of the college's gas into the host system.

\section{Line pressure on the coal}

seams will be dropped as low as possible, and the resulting gas and water production will be closely monitored. Back pressure regulators will be utilized on the deeper zones on each well in order to hold back pressure on these formations. This will allow for a determination of optimum producing line pressure for the Ravencliff Sandstone and Big Lime formations, while avoiding flooding of these zones.

The college projects that the compressor will be installed and operating by september 15, 1994, and that total gas production should increase from 50 to 100 mof per day.

\section{REFERENCES}

1. Overbey, W.K., T.K. Reeves, S.P. Salamy, C.D. Locke, H.R. Johnson, R. Brunk, and L.K. Hawkins. A Novel Geotechnical/Geostatistical Approach for Exploration and Production of Natural Gas from Multiple Geologic strata. Topical report submitted to U.S. Department of Energy, under Contract DE-AC2189MC26026, May 1991. 